\title{
MEZŐGAZDASÁGI CÉLÚ INTEGRÁLT MODELLRENDSZER MEGVALÓSÍTÁSA
}

\author{
Hollós Roland ${ }^{(1,2)}$, Fodor Nándor $^{(3)}$ (i), Hidy Dóra ${ }^{(1)}$, \\ Marton Tibor $^{(3)}$, Bottyán Emese ${ }^{(1,2)}$, Barcza Zoltán $^{(1,2)}$ (D) \\ ${ }^{(1)}$ ELTE TTK Kiválósági Tudásközpont, 2462 Martonvásár, Brunszvik u. 2. \\ ${ }^{(2)}$ ELTE Meteorológiai Tanszék, 1117 Budapest, Pázmány Péter sétány 1/A \\ ${ }^{(3)}$ MTA ATK, Mezőgazdasági Intézet, 2462 Martonvásár, Brunszvik u. 2. \\ e-mail: hollorol@gmail.com
}

\section{Bevezetés}

Magyarország területének 85\%-a mezőgazdasági művelés alatt áll. Az agrárszektorból származó jövedelem sok százezer család megélhetését biztosítja (KSH, 2017), amely ugyanakkor növekvő bizonytalansággal terhelt az egyre gyakrabban jelentkező szélsőséges környezeti feltételek miatt (Mäkinen et al., 2017). A mezőgazdaság fenntartható fejlödése kiemelt fontosságú feladat, aminek megoldásához több tudományterület szakértőinek összefogására, és világszínvonalú kutatási mühelyek létrehozására van szükség.

A korszerü, nemzetközileg is elfogadott szemléletmód szerint az agro-ökoszisztémák változó környezeti feltételekre adott válaszai és visszahatásai kizárólag ún. Integrált Modellrendszerek (IM) segítségével értékelhetők (Ewert et al., 2015). Ezek olyan számítógépes környezetek, amelyek a mezőgazdasági rendszer lehető legnagyobb szegmensének müködését igyekeznek szimulálni, beleértve a rendszer biogeokémiai, agrotechnikai és közgazdasági összetevőit, folyamatait és azok kölcsönhatásait. Segítségükkel megválaszolható többek között az a kérdés, hogy mi lesz a hőmérséklet emelkedésének, a nyári csapadékmennyiség csökkenésének és a légköri $\mathrm{CO}_{2}$ koncentráció emelkedésének eredő hatása az egyes haszonnövények terméshozamára. Vizsgálható, hogy hol vannak az országon belül azok a területek, ahol megtérülő befektetés lehet az öntözéses gazdálkodás fejlesztése. Számszerüsíthetjük, hogy milyen földhasználati mintázat esetén éri el a maximumát a mezőgazdaság jövedelmezősége a közeljövőben. Az IM-ek felhasználásával gyorsan és hatékonyan tesztelhetők a fenntartható fejlődés biztosítását célzó stratégia javaslatok, amelyek valós körülmények között történő tesztelése vagy eleve nem, vagy csak igen hosszú távon, esetleg csak aránytalanul nagy anyagi ráfordítással lenne lehetséges.

Az IM-ek egyelöre világszerte gyerekcipőben járnak. Az AgroMo projekt ${ }^{1}$ keretében a jelenleg fennálló infrastruktúra támogatásával lehetőség nyílik az első hazai IM megalkotására. Jelen tanulmány e kivitelezés alatt álló rendszer felépítését mutatja be. A hangsúly itt az ún. RBBGCMuso szoftveren van, ami a rendszer alapvető vezérlő eleme és integrátora.

\section{Az Integrált Modellrendszer}

Az Eötvös Loránd Tudományegyetem Kiválósági Tudásközpont (ELTE KT) és a Magyar Tudományos Akadémia Agrártudományi Kutatóközpont (MTA ATK) kutatóinak együttmüködésével jelenleg zajlik a hazai fejlesztésü Biome-BGCMuSo biogeokémiai modell mezőgazdasági célú fejlesztése (Hidy et al., 2016). A fejlesztések révén a modell képes a mezőgazdasági kultúrnövények (elsősorban búza és kukorica) produkciójának, termésmennyiségének és üvegházhatású gáz mérlegének számszerüsítésére. A jelenleg is zajló kutatás keretében a modellt beépítjük egy olyan saját fejlesztésü, grafikus döntéshozói szoftver-

\footnotetext{
${ }^{1}$ http://agromo.agrar.mta.hu
} 
környezetbe (AgroMo), ami lehetővé teszi különböző művelési módok tesztelését, és virtuális kísérletek végrehajtását Magyarország teljes területére. Ugyancsak lehetővé válik különböző korszerü klímaprojekciók beépítése, így a várható éghajlatváltozás hatásainak csökkentését célzó stratégiák kidolgozása is megvalósítható.

Az integrált modellrendszer megvalósulásának elengedhetetlen feltétele, hogy a rendszert definiáló részmodellek képesek legyenek egymással hatékonyan kommunikálni. Mivel ezidáig a részmodellek önálló külön egységet képeztek, a bemeneti és kimeneti adatformátumaik közti különbségek ezt a kommunikációt jelentősen megnehezítették. Az alábbiakban bemutatjuk az AgroMo részeit, amelyek integrációjaként áll elő a döntéshozók és gazdák számára készülő, egyszerü grafikus interfészen keresztül is használható IM.

\section{Biome-BGCMuSo}

A Biome-BGCMuSo (v5-től kezdődően) mára egy csatolt biogeokémiai-termény modellként jellemezhetö leginkább. A modell megörökölte az eredeti Biome-BGC (Thornton, 2000; Thornton et al., 2002), majd a Biome-BGCMuSo korábbi verzióinak a tulajdonságait (Hidy et al., 2016), és beépítésre került a hazai fejlesztésü 4M modellből (Fodor et al., 2003) több, mezőgazdasági haszonnövényekre jellemző mechanizmus (pl. virágzáskori hőstressz, vernalizáció, csírázás, stb.). A modell megőrizte univerzális jellegét, vagyis továbbra is használható tetszőleges biom modellezésére (fásszárúak, gyepek, cserjések), ami kiváló lehetőséget biztosít arra, hogy a teljes ország növényzetét modellezzük.

A modell kezelése nem egyszerü, mivel a mai napig parancssoros szoftverként használható (Linux, illetve Windows alatt). A felhasználó egy viszonylag hosszadalmas tanulási fázis után tudja csak elkészíteni a modell számára szükséges bemenő adatokat (meteorológia, ökofiziológia fájl, menedzsment lehetőségek, stb.). Ugyancsak problematikus a modelleredmények utófeldolgozása, amelyek sok esetben egyszerü bináris fájlként érhetők csak el, megnehezítve ezzel az adatok elemzését, ábrázolását, további számítások végzését.

\section{Agrárközgazdasági vonatkozások}

Az AgroMo keretrendszerben a Biome-BGCMuSo szimulációk eredményeit felhasználva képesek vagyunk „megsejteni” a magyar mezőgazdaság termelékenységének jövőbeli alakulását (hozamok, elöállított biomassza, stb.). Ezen termelési eredményeket összegezzük, illetve hatástanulmányt készítünk a klímaszcenáriókkal kiegészítve. Előzetes eredményeink alapján a biofizikális környezet változása inkább negatívan érinti Magyarország fő haszonnövényeinek hozamait. Célunk, hogy ezekre a kihívásokra megfelelő adaptációs stratégiát vázoljunk fel, így hozzájáruljunk az agrárszektor közép- és hosszútávú prosperitásához. A projekt gazdasági szekciójának érdeklödése középpontjában a modellezett farm-menedzsment döntések hatásfolyamatai (trajectories) állnak, ami keresi a stratégiai választ arra a kérdésre, hogy mikor, hol, és milyen változtatást (tőkebefektetést, struktúra-váltást) kell alkalmazni annak érdekében, hogy a klimatikus kihívásokkal szemben hatékony és kifizetődő válaszokat adjanak a gazdák.

\section{RBBGCMuso}

Ahhoz, hogy a fenti modelleket hatékonyan össze tudjuk kapcsolni, illetve további fejlesztési irányokat tudjunk meghatározni, szükség van egy közvetítő rétegre, amely dinamikusan képes az egyik modell kimeneti változóit a másik modell bemeneti változóiba alakítani. Erre alkalmas eszköz a saját fejlesztésü RBBGCMuso szoftver, amit a Biome-BGCMuSo "R" környezetbe való beágyazásának lehetősége miatt alkottunk meg (Hollós, 2017).

Az R szoftvercsomag egy közismert, nyílt forráskódú, statisztikai célú programozási nyelv, 
amely sikerességét elsősorban minőségi repozitóriumának - a CRAN-nak -, és szigorú minőségvédelmi elöírásainak köszönheti, amely emberi ellenőrzésen túl automatikus ellenőrző rendszereket is magába foglal ( $\mathrm{R}$ Core Team, 2018). Minden elérhető R kiegészítő csomagnak jól dokumentáltnak, valamint tesztelhetőnek, sőt hivatkozhatónak kell lennie. Mindezek eredményeképpen az R-ben írt eljárások, függvények, csomagok hatékonyan illeszkednek a tudományos projektek eszköztárába.

Az RBBGCMuso kialakításának motivációja az volt, hogy az elengedhetetlen utófeldolgozást egyesítsük a modell használatával (előfeldolgozással együtt), és számos olyan kényelmi funkciót tegyünk elérhetővé, ami általában csak nagyon komoly fejlesztés és matematikai tudás árán valósulhat csak meg.

Az R használatának nagy előnye, hogy elérhetővé válnak elö- és utófeldolgozási szinten azok az R csomagok is, amelyek a modellel való későbbi munkák alapjául szolgálhatnak. Lehetőségünk lesz például a Bayes alapú modelloptimalizációra (Trudinger et al., 2007), különböző érzékenységelemzések implementációjára. A továbbiakban az RBBGCMuSo R csomagról fogunk részletesebben írni.

\section{RBBGCMuso funkcionalitás, lehetőségek}

Az RBBGCMuso alkalmas eszköz a Biome-BGCMuSo modell bemeneti és kimeneti paramétereinek biztonságos és hatékony kezelése. Elsősorban már meglévő - előre összeállított fájlokkal dolgozik, de képes arra, hogy a bemeneti fájlokban található paraméterek többségét a fájlokban átírja, így az R környezetből kontextusváltás nélkül lehetséges a modell kezelése. Az RBBGCMuso felhasználásával nincs többé szükség külső szövegszerkesztőre, az input fájlok manipulálása után a modell manuális meghívására parancssorból, majd az eredmények Excelben (vagy más programnyelven) történő utófeldolgozására.

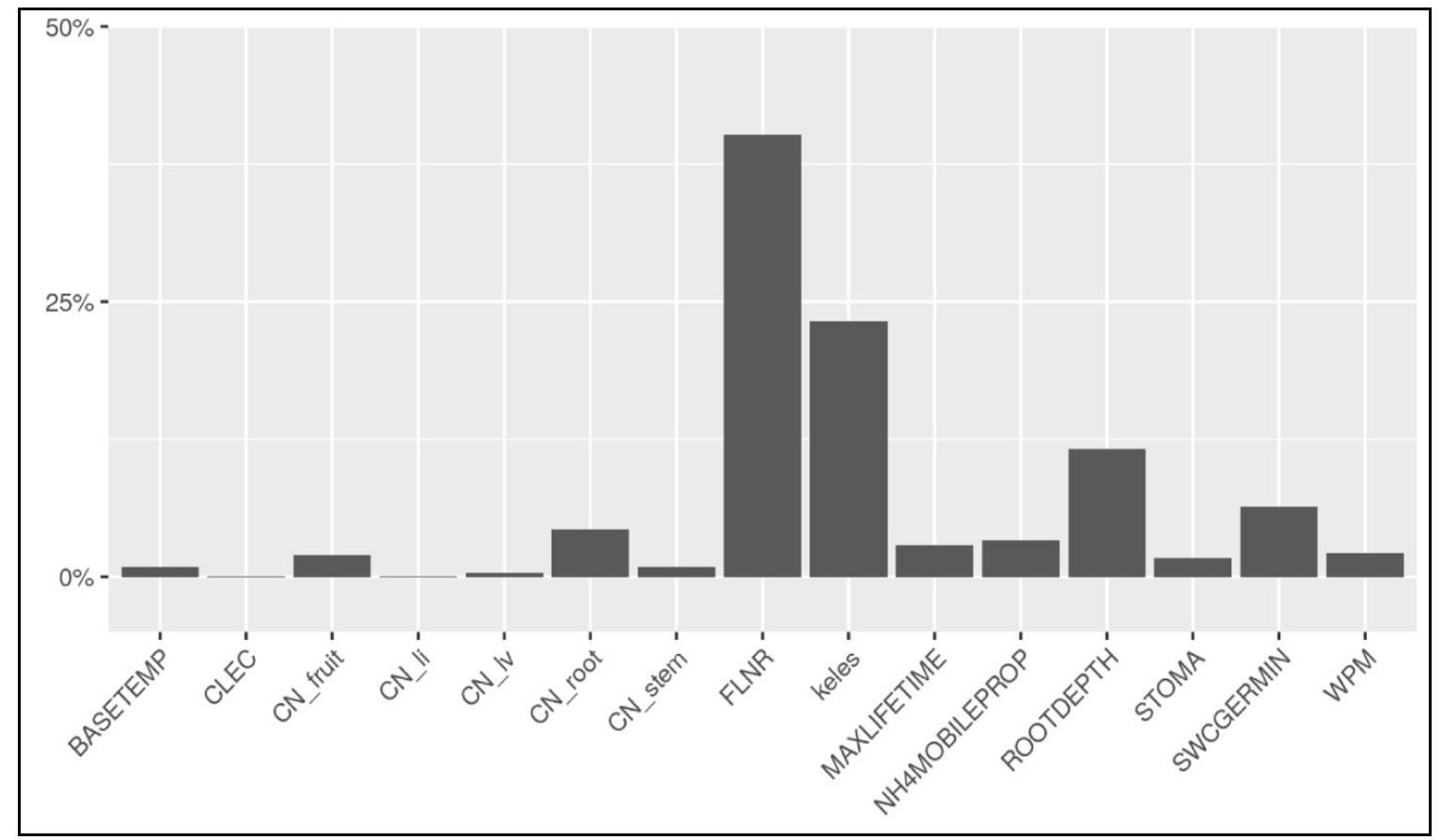

1. ábra: Az érzékenységelemzés eredménye az RBBGCMuso csomag implementációja alapján. A vízszintes tengelyen az ökofiziológiai bemeneti fájl néhány kiválasztott parametére olvasható, a relatív érzékenység (y tengely) alapján a Rubisco enzimben tárolt nitrogént (FLNR) meghatározó paraméter és a kelés időpontjának fontossága nyilvánvaló. 
Ezek a folyamatok váltak az RBBGCMuso-ban automatikussá. Az elkészült csomag kihasználva az $\mathrm{R}$ programozási nyelv lehetőségeit - mindezeken túl alkalmas a kimeneti adatok gyors vizualizációjára, Monte-Carlo szimulációk elvégzésére "Hit and Run" algoritmus (Smith, 1984) felhasználásával, amely a kalibráció mellett többek között az érzékenységelemzés alapjául is szolgál. A modell-optimalizálás első lépéseként egy lineáris regresszió alapú érzékenységelemzést (Verbeeck et al., 2006) végzö függvény is készült (1.ábra).

\section{1. táblázat: A legfontosabb RBBGCMuso függvények listája.}

\begin{tabular}{|c|c|}
\hline Függvény neve & Funkcionalitás \\
\hline setupMuso & $\begin{array}{l}\text { Inputfájlok, környezeti változók belolvasása, beállítása. A futta- } \\
\text { tás reprodukálhatóságáert felel. }\end{array}$ \\
\hline spinupMuso & $\begin{array}{l}\text { Lefuttatja a modellt spinup fázisban, opcionálisan az EPC és a } \\
\text { log fájlokat összegyújti és címkézi egy helyen. }\end{array}$ \\
\hline normalMuso & $\begin{array}{l}\text { Lefuttatja a modellt normal módban, beolvassa a bináris out- } \\
\text { putot, szűri szűrőfeltételek alapján. A függvény fejlett hiba- } \\
\text { kezeléssel lett beállítva. }\end{array}$ \\
\hline calibMuso & $\begin{array}{l}\text { A spinupMuso és a normalMuso együttese, továbbá a két futás } \\
\text { közti átmenetet is ellenőrzi. Ha a spinup nem fut le, akkor a nor- } \\
\text { mal sem. Opcionálisan ki tudja hagyni a spinup függvényt. A ki- } \\
\text { menetet MS Excelbe/csv-be/txt-be, ods-be, NetCDF-be tudja } \\
\text { exportálni. }\end{array}$ \\
\hline musoDate & $\begin{array}{l}\text { Egy adott beállításnak megfelelően legenerálja azokat a dátumo- } \\
\text { kat, amelyeken a modell futott, szökőévre való tekintettel, vagy } \\
\text { anélkül (felkészülve későbbi modellverziókra). }\end{array}$ \\
\hline plotMuso & calibMuso, grafikus exportálómodullal kiegésztve. \\
\hline musoMonte & $\begin{array}{l}\text { Hit and Run sampling algoritmust implementáló, a függőségeket } \\
\text { a függőségi gráf szomszédsági mátrixába konvertáló minta- } \\
\text { vételezési modul. }\end{array}$ \\
\hline musoQuickEffect & $\begin{array}{l}\text { Egy tetszőleges paramétert változtatva egy adott tartományban } \\
\text { annak adott számú osztópontjában lefuttatja a modellt, és egy } \\
\text { tetszőleges változó adott éves menetének változását vizualizáló } \\
\text { eszköz. }\end{array}$ \\
\hline parameterSweep & $\begin{array}{l}\text { A musoQuickEffect függvényt hatja végre tetszőleges számú } \\
\text { paraméteren, majd a kimeneti grafikonokat egyetlen HTML } \\
\text { dokumentumba exportálja, ahova a képelemek base64s kódolás- } \\
\text { sal kerülnek be, így a dokumentum független lesz a képi hivat- } \\
\text { kozásoktól. }\end{array}$ \\
\hline musoSensi & $\begin{array}{l}\text { Lineáris regresszió alapú érzékenységelemzést megvalósító függ- } \\
\text { vény. }\end{array}$ \\
\hline updateMusoMapping & $\begin{array}{l}\text { A kimeneti változókat és kódjaikat összekötő mátrix generálását } \\
\text { végző függvény tetszőleges modellverzió output_map_init.c } \\
\text { fájlát alapul véve. }\end{array}$ \\
\hline musoMapping & $\begin{array}{l}\text { Adott kimeneti változó kódjához tartozó változót megkereső } \\
\text { függvény. }\end{array}$ \\
\hline musoMappingFind & $\begin{array}{l}\text { A kimeneti változók között tudunk ún. "fuzzy matching”-et vé- } \\
\text { gezni ezzel a függvénnyel, így könnyüszerrel megtalálhatjuk egy } \\
\text { adott, számunkra érdekes változó kódját. }\end{array}$ \\
\hline
\end{tabular}


Az 1. táblázatban az RBBGCMuso fontosabb függvényeit soroltuk fel. További dokumentáció az RBBGCMuso csomag súgójában ${ }^{2}$ található. A táblázatban található függvényeket funkcionalitás szempontjából 7 csoportba sorolhatjuk:

1. futtattatási környezet beállítása, reprodukálhatóvá tétel (setupMuso, musoMapping, musoMappingFind)

2. modell futtatása (spinupMuso, normalMuso, calibMuso)

3. komplex lekérdezések lehetőségének megvalósítása (plotMuso, calibMuso, normalMuso)

4. kimeneti és bemeneti adatok gyors vizualizációja (plotMuso)

5. a modell debugolásának megkönnyítése (spinupMuso, normalMuso, calibMuso, plotMuso, musoQuickEffect)

6. bemeneti adatok dinamikus módosítása (normalMuso, calibMuso, musoMonte, musoSensi, musoQuickEffect, parameterSweep)

7. modelloptimalizálás eszközei

(musoMonte, musoSensi, musoQuickEffect, parameterSweep).

Az RBBGCMuso funkcionalitásánál azonban jóval fontosabb az az elv, amely mindezt megalapozza. A teljes csomag ugyanis az úgynevezett funkcionális programozási paradigma elvei szerint épült fel (Hughes, 1989). Ez az elv az erre képes nyelvek esetén garantálja, hogy minden egyes függvény ,tiszta” legyen, vagyis adott bemeneti adat egyértelmüen determinálja minden függvény esetén a kimeneti adatot. A hozzárendelés ez esetben egyértelmü, tehát minden függvény a funkcionális nyelvekben, matematikai értelemben is függvény. Ezzel elkerülhetjük az olyan eseteket, amikor ugyanolyan bemeneti feltételek mellett különbözö végeredményeket kapunk, ezzel biztonságossá válik a függvények használata. Ezzel a csomaggal válik igazán reprodukálhatóvá bármilyen modellfuttatás.

Hosszútávú tervünk, hogy a parancssoros Biome-BGCMuSo modell alapján, az RBBGCMuso környezet rugalmasságát és funkcionalitását kihasználva egy könnyen kezelhető, laikusok számára is hozzáférhető grafikus felhasználói felületet (angolul Graphical User Interface-t, azaz GUI-t) készítünk. A GUI a korszerü operációs rendszerek ismert grafikus elemeivel (gombok, csúszka, grafikonok, stb.) segíti a modell egyszerü használatát, és értelmezését. Nem utolsósorban alkalmas a modell oktatási célból való felhasználására. A GUI lesz a tervezett IM legfelső rétege, amely alatt rendre megtalálható lesz az RBBGCMuso, a HAREM, és legbelül, mint meghajtó motor, a Biome-BGCMuSo legújabb verziója.

A GUI-t egy példával szemléltetjük. Mivel a talaj-növény-légkör rendszer biogeokémiai dinamikájának egyik legfontosabb eleme a talaj vízháztartása, az RBBGCMuso tartalmaz egy olyan grafikus felhasználói felületet, amely egyidejüleg ábrázolja a csapadékot és a talaj különböző rétegeiben lévő víz mennyiségét is egy tetszőlegesen kiválasztott, valamint az azt megelőző, azt követő napon (2. ábra).

A továbbiakban a modelloptimalizációt GLUE (General Likelihood Uncertainity Estimation; Prihodko et al., 2008) módszer alapú kalibrációval tervezzük megvalósítani, ahol a kapcsolódó függvény az RBBGCMuso csomag része lesz.

Az RBBGCMuso szoftver lehetőséget nyújt a Biome-BGCMuSo modell egyszerü, de hatékony használatára, és emellett természetesen tudományos célra is felhasználható, ami nagyban segíti a biogeokémiai modellek alkalmazását és fejlesztését.

\footnotetext{
${ }^{2}$ https://github.com/hollorol/RBBGCMuso
} 


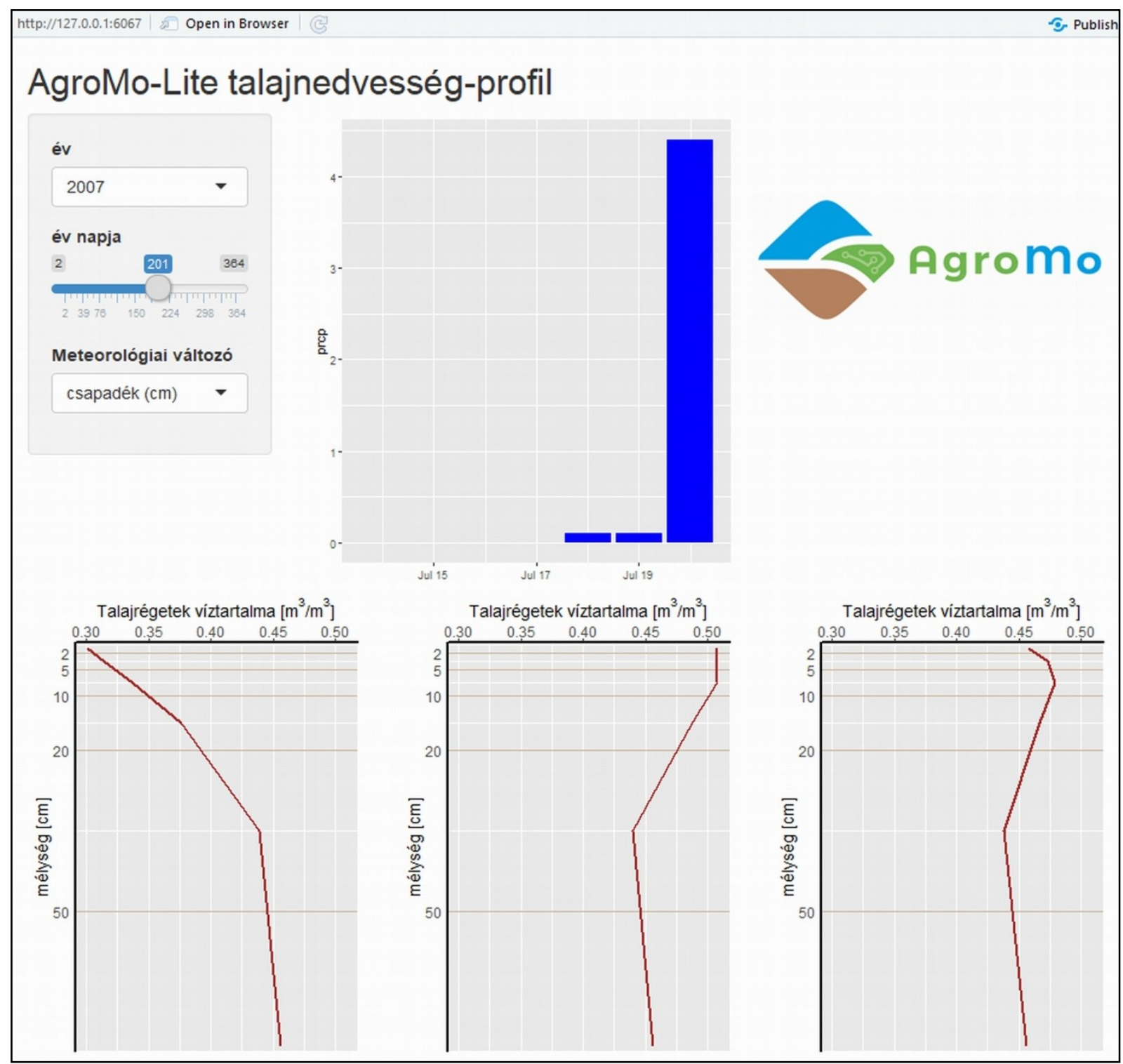

2. ábra: Talajnedvesség-profil GUI az RBBGCMuso-ban. Az ábrán 7 egymást követő nap csapadékmennyisége látható (felül középen, 2007. július 14-20), és 3 nap során a talajnedvesség-profil alakulása (alsó sor, 2007. július 19-21).

\section{Köszönetnyilvánítás}

A kutatást a Széchenyi 2020 program, Magyarország Kormánya és az Európai Regionális Fejlesztési Alap támogatja (GINOP-2.3.2-15-2016-00028).

\section{Hivatkozások}

Ewert, F., Rötter, R.P., Bindi, M., Webber, H., Trnka, M., Kersebaum, K.C., Olesen, J.E., van Ittersum, M.K., Janssen, S., Rivington, M., Semenov, M.A., Wallach, D., Porter, J.R., Stewart, D., Verhagen, J., Gaiser, T., Palosuo, T., Tao, F., Nendel, C., Roggero, P.P., Bartosová, L., Asseng, S., 2015: Crop modelling for integrated assessment of risk to food production from climate change. Environmental Modelling and Software, 72: 287-303. https://doi.org/10.1016/j.envsoft.2014.12.003 
Fodor, N., Máthéné-Gáspár, G., Pokovai, K., Kovács, G.J., 2003: 4M-software package for modelling cropping systems. European Journal of Agronomy, 18: 389-393. https://doi.org/10.1016/S1161-0301(02)00126-0

Hidy, D., Barcza, Z., Marjanović, H., Ostrogović Sever, M.Z., Dobor, L., Gelybó, G., Fodor, N., Pintér, K., Churkina, G., Running, S., Thornton, P., Bellocchi, G., Haszpra, L., Horváth, F., Suyker, A., Nagy, Z., 2016: Terrestrial Ecosystem Process Model Biome-BGCMuSo v4.0: Summary of improvements and new modeling possibilities. Geoscientific Model Development, 9: 4405-4437. https://doi.org/10.5194/gmd-9-4405-2016

Hollós, R., 2017: RBBGCMuSo: egy ökoszisztémamodell kiterjesztése. Szakdolgozat. Pécsi Tudományegyetem, Természettudományi Kar. Témavezető: Dr. Lóczi Dénes.

Hughes, J., 1989: Why functional programming matters. The Computer Journal, 32(2): 98-107. https://doi.org/10.1093/comjnl/32.2.98

KSH, 2017: A mezőgazdaság szerepe a nemzetgazdaságban. Elérés: 2017. november 10. https://www.ksh.hu/docs/hun/xftp/idoszaki/mezo/mezoszerepe16.pdf

Mäkinen, H., Kaseva, J., Trnka, M., Balek, J., Kersebaum, K.C., Nendel, C., Gobin, A., Olesen, J.E., Bindi, M., Ferrise, R., 2017: Sensitivity of European wheat to extreme weather. Field Crops Research, 222: 209-217. https://doi.org/10.1016/j.fcr.2017.11.008

Prihodko, L., Denning, A. S., Hanan, N. P., Baker, I., Davis, K., 2008: Sensitivity, uncertainty and time dependence of parameters in a complex land surface model. Agricultural and Forest Meteorology, 148: 268-287. https://doi.org/10.1016/j.agrformet.2007.08.006

$R$ Core Team, 2018: R: A language and environment for statistical computing. R Foundation for Statistical Computing, Vienna, Austria. Retrieved from https:/www.R-project.org/

Smith, R.L., 1984: Efficient Monte Carlo procedures for generating points uniformly distributed over bounded regions. Operations Research, 32: 1296-1308. https://doi.org/10.1287/opre.32.6.1296

Thornton, P.E., 2000: User's Guide for Biome-BGC, Version 4.1.1. Available online at ftp://daac.ornl.gov/data/model archive/BIOME_BGC/biome bgc 4.1.1/comp/bgc usede $\underline{41 . p d f}$

Thornton, P.E., Law, B.E., Gholz, H.L., Clark, K.L., Falge, E., Ellsworth, D.S., Goldstein, A.H., Monson, R.K., Hollinger, D., Falk, M., Chen, J., Sparks, J.P., 2002: Modeling and measuring the effects of disturbance history and climate on carbon and water budgets in evergreen needleleaf forests. Agricultural and Forest Meteorology, 113: 185-222. https://doi.org/10.1016/S0168-1923(02)00108-9

Trudinger, C.M., Raupach, M.R., Rayner, P.J., Kattge, J., Liu, Q., Pak, B., Reichstein, M., Renzullo, L., Richardson, A.D., Roxburgh, S.H., Styles, J., Wang, Y.P., Briggs, P., Barrett, D., Nikolova, S., 2007: OptIC project: An intercomparison of optimization techniques for parameter estimation in terrestrial biogeochemical models. Journal of Geophysical Research, 112: G02027. https://doi.org/10.1029/2006JG000367

Verbeeck, H., Samson, R., Verdonck, F., Lemeur, R., 2006: Parameter sensitivity and uncertainty of the forest carbon flux model FORUG: a Monte Carlo analysis. Tree Physiology, 26: 807-817. https://doi.org/10.1093/treephys/26.6.807

\section{ORCID}

Fodor N. (iD) https://orcid.org/0000-0002-6460-1767

Barcza Z. (iD https://orcid.org/0000-0002-1278-0636 